\title{
Military Spending and Economic Growth Relationship in the Case of France, ARDL and Causality Analysis
}

\author{
Masoud Ali Khalid \\ Hatem Hatef Abdulkadhım Altaee
}

College of Financial \& Administration- Department of Accounting \& IT, Cihan University, Sulaimani,

Kurdistan Region Government, Iraq; * Email of the corresponding author: masoudqajry@yahoo.com

Doi:10.5901/mjss.2015.v6n4p178

\begin{abstract}
Over the last 3 decades, there has been a remarkable amount of empirical study on the defense-growth relationship, applying various models and econometric methods by concentrating on individual case researches, time series, and panel data studies or cross country investigations. In spite of the number and the diversity of researchers, the evidence of the defense-growth correlations are still far from conclusive. In addition, few studies have focused on the case of France. To fill in the gap in the literature, this paper employs an autoregressive distributed lag and granger causality test to provide empirical evidence on the economic effects of defense expenditure between 1970-2010. All in all, the result derived from autoregressive distributed lag $(A R D L)$ is consistent and suggests that significant and positive correlation exist between economic and military sector in both short and long term. The Granger causality result outcomes show a unidirectional relation running from gross domestic product per capita to the defense expenditure. This is an indicated that gross domestic product is very significant to the defense sector in France.
\end{abstract}

Keywords: Military Expenditure; Economic growth; ARDL; Granger Causality, France.

\section{Introduction}

The recent financial crisis, and the following budget restraints, has led European Union nation's to face with a trade-off between military spending and social spending. On the one hand, European people require social expenditure instead of military expenditure because they believe that, there are no military intimidation against European nation's. On the other side, there is a broad desire to constructing a Europe that is reliable in the worldwide defense scenario. Some European nation's supporter a powerful combine and independent Europe as an alternative to the United States force and dominated, unipolar as global order. For this reason, it requires to follow common and coordinated policies under the European Security and Defense strategy, rather than taking unilateral decisions.

The one-sided decisions of some European countries to decrease their military budget such as. France, Italy, Spain, Denmark, and Belgium erode the unclear autonomy of a worldwide reliable. Usually, one of the primary goods required by any nation in the world is the degree of development rather than demands for the military sector.

Nevertheless, with the passing of time, the demand for military and security has increased in so many countries for several reasons. Firstly, free-rider behaviors appear because defense and security are pure public goods and, therefore, there is no revelation of preferences. Secondly, particularly in European nation's, other government and social spending, for example health and education are much more demanding of the population rather than military spending. Furthermore, there is also a trade-off between defense spending and other government expenditure such as social expenditure which makes it difficult to justify the military expenditure to the government in these nations. In this situation, politicians have to encourage their government to reduce defense spending in order to increase the number of votes.

Global leadership and strong demonstration in reliable worldwide institutions, for instance the UN, EU, and NATO are the major driving forces. They are mostly determined by the degree to which a country is involved in global concerns. It is logical that the larger worldwide contribution, the stronger the global leadership and so the healthier the global relationships. Additionally, improving the local economic situation is another argument to support military spending for a number of nation's.

Considering this multiplicity of paths, France is an interesting case of study because there are a few recent attention in the literature. This is surprising given the peculiarities of French military policy and the economic importance of defense spending. Some figures help GDP was $3.75 \%$ and the defense sector shared by $21.5 \%$ of government expenditure. Julien Malizard (2013)

Employments in the military sector constituted a huge part of the public workforce by (8\%), and there was an 
increase of 1.9\% between 2006 and 2009 in real terms without incomes and 2.3\% including incomes. In order to manage the negative effect of the international economic recession in 2008 and then motivate financial growth, the French government has decided to inject 26 billion euros into the economy. More than half of this money was provided to sustain companies in financial crises (the financial sector) and the rest to public spending (11 billion euros), Julien Malizard (2010). According to (SIPRI 2012), France is one of the top global defense spending, and it's ranked sixth.

The economists believe that, military expenditure has a positive impact on the economic growth in France because investing in the military sector is related policy answer to the because of the development of essential technologies, the making of high skilled jobs and the technological spillovers on civilian activities. Thus, increasing the military budget is an economic policy tool which helps France limits the financial recession. The main aim of this paper is to assess the impact of military expenditure on economic growth by applying the ARDL model which introduced by Pessaran (2001)

The remainder of the article is organized as follows. The next part provides an overview of the theoretical and empirical study The third part presents the military expenditure in France. The econometric methodology is discussed in the fourth part and the empirical results are presented in the fifth part. In the final part we conclude this article.

\section{Literature Review}

Military expenditure constitutes an important share of international economic resources, but despite of it's a vital size, its economic effect has only recently been a concern of analysis in economic theory. The theoretical investigation of defense spending becomes much more harder hard as it is not a purely economic issue, but rather a mixture of economic, strategic, cultural, and even moral aspects. Even though most economic theory does not have a clear role for defense expenditure as a separate economic activity, there are four main theoretical methods (the Keynesian, the Neoclassical, the Liberal and the Marxist theory) that clarify defense spending from different points of view. (See, Smith (1977), Georgiou (1983) and Dunne (1990, 1996).

In the Keynesian theory, military expenditure is a proactive and interventionist, using it to enhance production through multiplier impacts when total demand is ineffective (Dunne, 1996) and Faini et al. (1984) also mentioned that if total demand is low relative to potential supply, increases in defense spending could lead to raise capacity utilization, and increased profits and later, raised economic growth and investment. Moreover, in the empirical literature, Keynesian demand-side theories are generally used to describe defense-growth correlation. Empirical study within this demandconcentrated model tends to find a negative correlation between defense spending and growth (through the crowding out of investment). The main drawback of this framework is that it emphases on the demand-side rather than the supply-side issues (technology spin-offs and externalities). Smith and Smith (1980) was the first researcher to include explicit output functions in order to overcome this issue by focusing on the demand side only.

Marxists believe militarism and defense spending as a social phenomenon with a historical aspect and they concentrate on the socio-political and strategic aspects of defense spending and not so much on the economic ones. They had discussed that military expenditure increases economic growth by preventing crises or by acting as an informal industrial policy (Dunne, 1990). Within this school of thought, there is one theoretical perspective that has an essential role for defense spending. The under consumptions approach progressed by Baran and Sweezy (1966) claims that as a capitalist economy grows up, the available surplus grows beyond that absolutely necessary for consumption and also for investment. So, within the under consumptions outline, defense spending will be beneficial to economic when the economy is in disequilibrium.

In contrast, neoclassical theory has a different opinion about economic growth and defense spending, and they see defense spending as a pure public good supplied by the government. So, the government can appear as a rational player that tries to maximize state interest by balancing opportunity costs and security benefits of defense spending. In the empirical study, supply- side models of the military expenditure and economic growth correlation within the neoclassical theory derive from the total production function.

Generally, a supply-side model was developed by Feder (1982) and elaborated by Ram (1986) and Biswas and Ram (1986) who considered defense spending as an exogenous variable and estimated its dynamic real impacts on production. Nevertheless, a recent critique by Dunne et al. (2005) criticized the Feder-type model both in terms of econometric and theoretical issues. Another growth models that have used in the defense-growth study are the Barro (1990) model applied by Aizenman and Glick, (2003); Mylonidis, (2008); Pieroni, (2009) and the augmented Solow growth model introduced by Mankiw et al. (1992) and applied by Knight et al. (1996).

Moreover, Halicioglou (2004) following Atesoglou (2002) developed and progressed the new macroeconomic model of Romer (2000) and Taylor (2000) that replaces the standard IS-LM and AD-AS methods and delivers a more detailed account of monetary and fiscal policies on the national income. Many of the recent researchers avoid a reliance 
on ad hoc specifications and tend to be based on well-specified theoretical model usually the Keynesian and the neoclassical model - that let the development of consistent formal models.

All in all, while the empirical study's offer no consensus on the effects of defense expenditure on economic growth, the most important finding is that the defense expenditure has either no significant or a negative impact on growth of less developed nations. Chan (1988), Ram (1995), and Dunne (1996).

In addition, a few investigations concentrated on the case of France to examine defense correlation such as Julien Malizard $(2010,2013)$. The first study evaluates the growth-military relationship over span 1960-2008; he employed granger causality model, and he found that, a bidirectional causality exists in the long term between military expenditure and gross domestic product (GDP). Furthermore, the authors also discussed that, any increase in the military sector might be encouraging growth in the economy. The second study examined the opportunity cost of defense spending, he found that, in the long-term military spending exerts a positive effect and outperforms the effect of non military spending. On the other hand, an opportunity cost increase in the short term. These results indicate that the defense - growth relationship is positive and significant in the case of France.

\section{Defense Expenditure in France}

Given the economic situation in France and the impacts of the crisis in public economics, and given the inherited charges and ongoing spending, French military considerable challenges in the medium and short term. Despite of an annual budget of forty billion Euros and 320, 0000 defense and civilian personnel expenditure, France's military spending continue the purview of a closed circle of defense staff, suggesting that, public opinion shares a permanent, a political vision of military issues that does not justify public debate. It is as if Europe's leading defense power alongside the UK, a permanent member of the UN Security Council, armed with nuclear weapons and a full member of NATO, stimulates indifference in French public opinion concerning its determinations as a defense power and the means to achieve them. But surely Frances participation in Afghanistan and Libyan operations in 2011, mobilizing 7,800 troops directly involved in combat operations, should stimulate a more substantial debate about the country's role on the global phase.

Although military expenditure is the fourth budget item in France, it is rarely a matter of public discussion. In the last four decades, military expenditure has affected in turn by the desire to rip the benefit of the post-Cold war "peace dividend", the professionalization of 1997, and the rise of a broad defense operation after the nine eleven 2001. These fluctuations happened in a constrained social and economic framework, in which defense expenditure had played the major role of the expandable line- regardless of the majority in power. After a decade of continuous growth of global defense expenditure, it seems appropriate to investigate and question the budgetary choices that will decide on the future of French military capability.

Moreover, over the last three decades, the French military budget has undertaken a profound transformation, sometimes against the current of general European trends, in spite of clearly identified strategic determinations, sometimes in return for a radical re-formatting of the armed forces, and other times as a result of a change of government. Long considered as ring-fenced, defense today is one of the most susceptible ministries to budget cuts. Before investigating the causes and consequences of these economic changes, it is crucial to recall that military policy choices reflect not only France's commitment to the global stage and its multi-dimensional role (EU, NATO and UN), but also its strategic vision of the post-cold war environment. In the ideal global, i.e. With no budget restraints, France would occupy a privilege position as a defense power with an eye on leadership in the EU, Martial Foucault (2012). In reality, marked by a context of budget severity, how do so-called defense powers managed to maintain their global ranking with deteriorating a country's global "posture" with its military budget, it is more relevant to look at the budget decisions for each expenditure item for each of the services in the long run.

Table I: France Defense Spending as a percentage of GDP (1988-2012).

\begin{tabular}{cccccc}
\hline & $1988-1992$ & $1993-1997$ & $1998-2002$ & $2003-2007$ & $2008-2012$ \\
\hline & 3.6 & 3.3 & 2.7 & 2.6 & 2.3 \\
& 3.5 & 3.3 & 2.7 & 2.6 & 2.6 \\
& 3.4 & 3.0 & 2.5 & 2.5 & 2.4 \\
Average & 3.4 & 2.9 & 2.5 & 2.4 & 2.3 \\
& 3.3 & 2.9 & 2.5 & 2.3 & 2.3 \\
\hline
\end{tabular}

Source: SIPRI (2013). 
As we can observe from Table I, average defense spending as a share of GDP was 3.44, this percentage regularly has decreased between 1993 to 1997 from 3.44\% to 3.08\% and this decreasing continued for the following years for instance its military spending has reduced from $2.58 \%$ to $2.38 \%$ between $1998-2012$. It means that despite the positive correlation between military sector and economic growth, military expenditure is not encouraged by the France government to stimulate growth rate.

\section{Methodology}

\subsection{Data and Unit Root Test}

The three variables have used in this article, such as real GDP, real defense spending and real export by using timeseries data for over the spans 1970-2011. We have collected our data from different sources. For instance, the data on (GDP) and real export are collected from World Development Indicator (WID), and for defense spending are obtained from Stockholm International Peace Research Institute (SIPRI).

Furthermore, we begin the empirical analysis with an investigation of the unit root test for the variables. We have assumed that, the data we have used in this study are stationary. If the results of stationarity are violated, this may be lead to spurious results. In investigating the time-series data properties, there are several methods to test the stationarity, but the most important one is the Augmented Dickey-Fuller (ADF) (Dickey and Fuller, 1979, and the Phillips-Peron (PP) (Phillips and Peron, 1988) unit root tests.

\subsection{Autoregressive Distributed Lag (ARDL) Model and Co-integration Analysis}

To examine the time series data in different order I(1) and I(0) together, Pesaran et al. (2001) suggested that, the Autoregressive distributed lag approach (ARDL) to test for co-integration as an alternative approachable to co-integration model for Engle-Granger (1989). In This article we will use the ARDL method to examine the short and the long term between defense spending and GDP in the case of France. The ARDL bond testing approach for co-integration can be written:

$$
\begin{aligned}
& \Delta \mathrm{GDP}_{\mathrm{t}}=\alpha_{0}+\sum_{\mathrm{i}=1}^{\mathrm{p}} \alpha_{1} \Delta \mathrm{GDP}_{\mathrm{t}-\mathrm{i}}+\sum_{\mathrm{i}=0}^{\mathrm{p}} \alpha_{2} \Delta \mathrm{ME}_{\mathrm{t}-\mathrm{i}}+\sum_{\mathrm{i}=0}^{\mathrm{p}} \alpha_{3} \Delta \mathrm{EX}_{\mathrm{t}-\mathrm{i}}+ \\
& +\delta_{\downarrow} \mathbf{1} \mathrm{GDP}_{\downarrow}(\mathbf{t}-1)+\delta_{\downarrow} 2 \mathrm{ME}_{\downarrow}(\mathrm{t}-1)+\delta_{\downarrow} 3 \mathrm{EX}_{\downarrow}(\mathrm{t}-1)+\mu_{\downarrow} \mathbf{t}
\end{aligned}
$$

Here $\Delta$ is the first difference operator, $\Delta \mathrm{GDP}_{\mathrm{t}}$ stands the natural log of real GDP, $\Delta \mathrm{ME}$ stands the natural log of real military expenditure, $\Delta \mathrm{EX}$ stands the natural log of real export, and $\mu_{\square}$ stands the error correction term.

The $F$ test is used to determine whether the long-term correlation relationship exists between the variables through testing the significance of the lagged levels of the variables. When, this correlation exists, then, the $F$ test indicates that our variables should be normalized.

The null hypothesis of no co-integration amongst the variables in the equation (1) is

$\delta_{\mathbf{1}}=\delta_{\mathbf{2}}=\delta_{\mathbf{3}}=0$ Against the alternative hypothesis $\delta_{\mathbf{1}} \neq \delta_{\mathbf{2}} \neq \delta_{\mathbf{3}} \neq 0$

The $F$ test has not a standard distribution that depends on; (1) whether the variables are included in the ARDL approach are I(0) or I(1); (2) the number of independent variables; (3) whether the ARDL approach contains an intercept and a trend; and (4) the sample size of the variables. The rejection of the null depends on the F-test and the critical bound tabulated value for small sample size according to Narayan (2005).

The long-term correlation among the variables exists if the calculated value of the $\mathrm{F}$ - statistic is greater than the upper critical bound test, and if the calculated value of F- statistic is smaller than the lower critical bound, the long-term correlation does not exist, if the calculated value of the F-statistic comes in between the range of LCB and UCB then the long-term correlation is inconclusive. Mintz, (1991) and Hassan \& Kalim, (2012). The optimal lag can be selected using the model selection criteria like Akaike Information Criterion (AIC). According to Narayan (2005) the maximum lags for small sample size is two lags.

\section{Empirical Results}

Table II shows the result of the stationary test for ADF-test and PP test, respectively for the case of France. Both tests indicated that GDP has a unit root at level, but it becomes stationary at first difference, which implies that GDP is I (1). Nevertheless, other two variables were found to be significant at first difference and thus it shows that the variables are I (1). 
Based on our result the variables are either I(0) or I(1), consequently, implying that we can confidently apply the ARDL model to this study as using ARDL requires the data to be stationary at the level I (0) and first difference I(1) (Narayan, 2005).

Table III represents the long-term co-integration test analysis, and the existence of a long-term correlation which has found between the model's variables. Our result reveals that the F-statistic is 5.3122. The relevant critical value bound at 10\% (with unrestricted intercept and no trend) are 4.133 and 5.260 and for the lower and upper bounds respectively. Subsequently, the F-statistics are higher than the critical value of the upper bound test, the null hypothesis of no long run cointegration correlation among the variables can be simply refused. Moreover, the existence of the long-term associated between real GDP defense spending, and export. The model can be used to evaluate the long and short-term parameters.

In addition, this study also reports the main estimation results here and looks at the long-term growth-defense correlation These results are provided in Table IV. In the estimation model, the dependent variable is real GDP per capita (LGDP). The results show a positive and significant relationship between government, military expenditure $\left(M E_{t}\right)$, export $\left(E X_{t}\right)$ and gross domestic Product (GDP) in the long-run. The results reveal that any increase of defense spending and export are related to. To be precise, improvement of military expenditure and export by $1 \%$ leads to $0.580 \%$ and $2.25 \%$ respectively increase in GDP per capita. A significant and defense-growth relationship has reported in the literature similar to Julien Malizard (2010) and Julien Malizard (2013).

Table V shows the estimated ARDL error correction approach. The results illustrate that both variables are statistically significant at 1 and 5 level. Specifically, government military expenditure (DLME) and real export are (DLEX) positive and significant at $1 \%$ and $5 \%$ level respectively. For instance, improvement in the military expenditure and export in the short-run is related to improvement in Gross Domestic Product. It can be seen from the results, military spending has an important effect economic growth. So, with this investigation, it can be stated that defense spending can promote growth and that its impacts seem to be quite lasting over time, even though the magnitude is rather small. As a result, military sector indicates a prolonged effect on the economy in the short-term. In other words, this finding agrees with the Keynesian theory which states that increased military expenditure stimulates demand and increases output. To be exact, improvement of military expenditures and export by $1 \%$ leads to rise in GDP by $0.84186 \%$ and $0.029105 \%$ respectively. Lipow, (1995) found that the effect of defense spending on economic is essential variable, and found to be positively related to GDP per capita in the short-run. These findings are consistent with some recent empirical investigations such as Yildirim et al. (2005); Kollias et al. (2007); Halicioglu (2004); Dunne et al. (2001); and Atesoglu, (2002). The findings of the analysis also lend support to the earlier studies in the literature (see Benoit, 1973, 1978; Deger, 1986; Sezgin, 1997; 2000).

Table $V$ reveals the result of Granger causality test, which shows a unidirectional correlation running from a GDP per capita to the military expenditure. This shows that GDP is essential to the defense sector in France, and efforts need to be geared towards increasing the GDP per capita to enhance the military expenditure.

Table II: ADF and PP unit root test results.

\begin{tabular}{|c|c|c|c|c|}
\hline \multicolumn{3}{|c|}{ ADF } & \multicolumn{2}{|l|}{ Philip-Perron } \\
\hline \multicolumn{5}{|c|}{ Level } \\
\hline & Intercept & Intercept and trend & Intercept & Intercept and trend \\
\hline$G D P_{t}$ & -1.715171 & -2.459618 & -1.861813 & -1.590107 \\
\hline$M E_{t}$ & -4.968409 * & $-6.015342^{*}$ & $-4.932968^{*}$ & $-10.71829^{*}$ \\
\hline$E X_{t}$ & -1.634632 & $-3.355199^{* \star *}$ & -1.597490 & -2.344023 \\
\hline \multicolumn{5}{|c|}{ 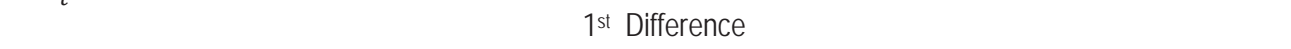 } \\
\hline$G D P_{t}$ & $-4.621860^{*}$ & $-4.794549^{*}$ & $-4.394975^{\star}$ & $-4.667337^{*}$ \\
\hline$M E_{t}$ & $-8.239342^{*}$ & $-8.108106^{*}$ & $-18.99220^{*}$ & $-18.53070^{*}$ \\
\hline$E X_{t}^{\imath}$ & $-3.200310^{* *}$ & -3.115588 & $-2.839934^{* *}$ & -2.718353 \\
\hline
\end{tabular}

"Denotes significant at 1\%, ${ }^{*}$ Denotes significant at $5 \%,{ }^{* * *}$ Denotes significant at $10 \%$.

Table III: ARDL Bounds Test for Co-integration

\begin{tabular}{ccccccc}
\hline \multicolumn{2}{c}{ Lag structure: } & \multicolumn{3}{c}{$1,1,0$} \\
\hline F-statistics & \multicolumn{2}{c}{$5 \%$ Critical value } & \multicolumn{2}{c}{$10 \%$ Critical value } \\
& $\mathrm{I}(0)$ & $\mathrm{I}(1)$ & $\mathrm{I}(0)$ & $\mathrm{I}(1)$ & $\mathrm{I}(0)$ & $\mathrm{I}(1)$ \\
$5.3122^{\text {** }}$ & 5.893 & 7.337 & 4.133 & 5.260 & 3.373 & 4.377 \\
& & & $\mathrm{~K}=2, \mathrm{~N}=40$ & & & \\
\hline
\end{tabular}

The critical value according to Narayan (2005) (Case III: Unrestricted intercept and on trend)

$\left.{ }^{*},{ }^{*}\right),\left({ }^{* *}\right)$ Significant at $1 \%, 5 \%$ and $10 \%$ respectively. 
Table IV: Long Run Relationship (Dependent variable: LGDP)

\begin{tabular}{ccc}
\hline \multicolumn{2}{c}{ Lag Structure } & $(1,1,0)$ \\
\hline & Dependent variable: Gross Domestic Product (LGDP) & \\
Regressors & Coefficient & T-Ratio [Prob] \\
constant & $-5.6601^{* *}$ & $-1.8495[.073]$ \\
$L M E_{t}$ & $.58033^{* *}$ & $2.0636[.047]$ \\
$L E X_{t}$ & $.18356^{* *}$ & $2.2566[.030]$ \\
\hline
\end{tabular}

Notes: t-value in the parentheses (....) and p-value of diagnostic test in parentheses.

The critical value according to Narayan (2005) (Case III: Unrestricted intercept and on trend) $\left.{ }^{*},{ }^{(*)}\right),\left(^{* * *}\right)$ Significant at 1

$\%, 5 \%$ and $10 \%$ respectively.

Table V: Short Run Relationship (Dependent variable: DLGDP)

\begin{tabular}{|c|c|c|}
\hline Lag Structure & & $(1,1,0)$ \\
\hline \multicolumn{3}{|c|}{ Dependent variable: Gross Domestic Product (DLGDP) } \\
\hline Regressors & Coefficient & T-Ratio [Prob] \\
\hline Constant & -.89745 & $-1.6315[.112]$ \\
\hline DLME & $.84186^{\star}$ & $11.1169[.000]$ \\
\hline$D L E X$ & $.029105^{\star * *}$ & $1.9634[.057]$ \\
\hline$E C T_{t-1}$ & $-.039205^{* \star *}$ & $-1.1063[.071]$ \\
\hline
\end{tabular}

${ }^{*},\left({ }^{* *}\right),\left({ }^{* * *}\right)$ denotes Significant at 1\%, 5\% and 10\% respectively. Lag lengths are $(1,1,0)$ selected based on Schwarz Bayesian criterion (SBC).

Table VI: Granger Causality Test

\begin{tabular}{lc}
\hline Null Hypothesis & F-Statistic(Prob.) \\
LME does not Granger Cause LGDP & $0.21519(0.8074)$ \\
LGDP does not Granger Cause LME & $5.33016^{*}(0.0095)$ \\
\hline The critical value according to Narayan (2005) (Case III: Unrestricted intercept and on trend) \\
$\left.{ }^{*},{ }^{* *}\right),\left(^{* *}\right)$ Significant at 1\%, 5\% and 10\% respectively. \\
\hline
\end{tabular}

Ultimately, we have analyzed the stability of the long and long term coefficients. In doing so, we have followed Pesaran and Pesaran (1997), and apply the CUSUM and CUSUMSQ [proposed by Brown, Durbin, and Evans (1975)]. The tests are applied to the residuals of all two models. Particularly, the CUSUM test makes use of the cumulative sum of recursive residuals based on the first set of $n$ observations and is updated recursively and plotted against break points. If the plot of CUSUM statistics stays within the critical bounds of $5 \%$ significance level [represented by a pair of straight lines drawn at the $5 \%$ level of significance whose equations are given in Brown, Durbin, and Evans (1975)], the null hypothesis which all coefficients in the (ECM) are stable that cannot be refused. If either of the lines is crossed, the null hypothesis of coefficient constancy can be rejected at the $5 \%$ level of significance. A similar procedure is used to carry out the CUSUMSQ test that is based on the squared recursive residuals. Figure 2 indicates a graphical representation of the CUSUM and CUSUMSQ plots applied to the (ECM) selected by the adjusted R2 criterion. Neither CUSUM nor CUSUMSQ plots cross the critical bounds, showing that there is no any evidence of significant structural instability. Same results followed when the tests were applied to the other two methods.

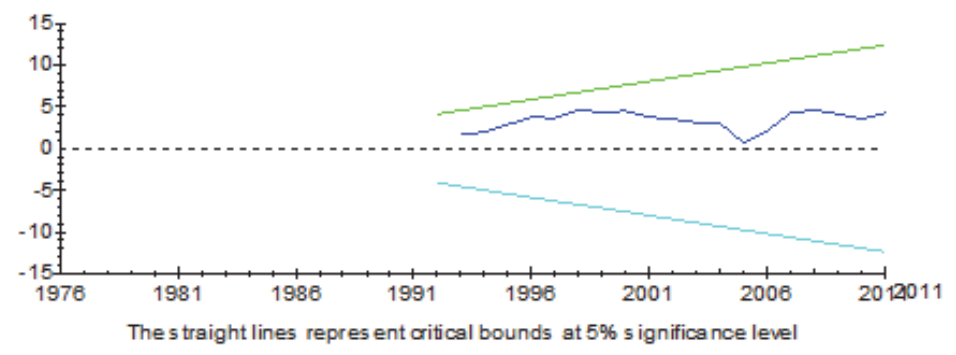

Figure 1. Cumulative Sum of Squares of Recursive Residuals (Long run relationship) 


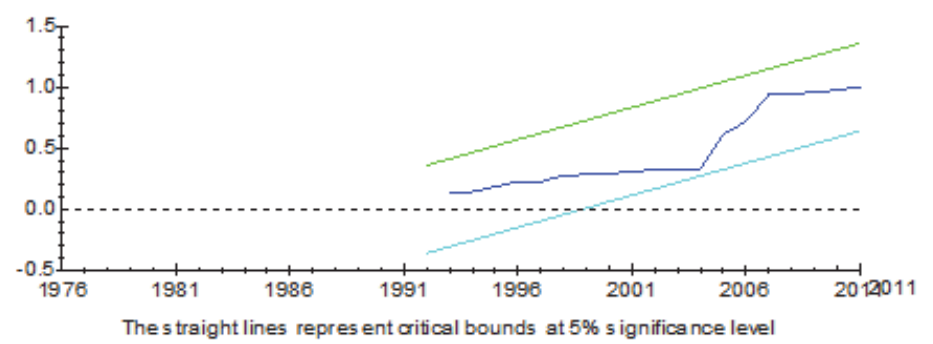

Figure 2. Cumulative Sum of Recursive Residuals.

\section{Summary}

A huge and growing body of literature investigates the military-growth relationship with no robust empirical regularity emerging. Hoping to contribute to the existing body of the literature, this paper set out to examine the interaction between defense spending, export and economic growth in the case of France for the period 1988-2006, which is one of the few cases that deal with the post-cold war period. Additionally, defense expenditure is a kind of spending by governments that has an important effect beyond the economic resources it takes up, particularly when it leads to or facilitates conflict. Its economic effect is thus of considerable concern.

The massive changes in the defense expenditure in the past forty years have raised the variation in the data, making it more likely that empirical analysis would be able to distinguish any underlying macroeconomic correlation from noise. Combining this with autoregressive distributed lag model and granger causality methods gives us the possibility to identify more clearly any empirical growth-defense relation. The results of the ARDL approach have provided evidence that is consistent with the previous literature, and we have found that defense spending has a positive, highly statistically significant effect on the share of general government expenditure as a percentage of GDP in the short and long run. Furthermore, the result of the Granger causality test indicates a unidirectional causality between defenses spending growth rate, especially this relationship is running from a GDP to the defense expenditure. This illustrates that GDP plays a major role in the defense sector in France and efforts need to be geared towards increasing the GDP to enhance the military sector in France. The main important policy implication we can derive from these results is that the France governments could benefit from an increase in the ratio of GDP to military sector and improve in the defense spending. Hence, these two variables should be used as instruments by the France governments when aiming at increasing economic growth and defense expenditure.

\section{References}

Aizenman, J. and R. Glick (2003). Military expenditure, threats, and growth, National Bureau of Economic Research.

Atesoglu, H. S. (2002). "Defense Spending Promotes Aggregate Output in the United States--Evidence from Cointegration Analysis." Defense and Peace Economics 13 (1): 55-60.

Baran, P. A. and P. M. Sweezy (1966). Monopoly Capital. An Essay on the American Economic and Social Order, Paul A. Baran and Paul M. Sweezy, Monthly review P.

Barro, R. J. (1991). "Economic growth in a cross section of countries." The quarterly journal of economics 106(2): 407-443.

Biswas, B. and R. Ram (1986). "Military expenditures and economic growth in less developed countries: an augmented model and further evidence." Economic Development and Cultural Change 34(2): 361-372.

Brown, Robert L., James Durbin, and John M. Evans. "Techniques for testing the constancy of regression relationships over time." Journal of the Royal Statistical Society. Series B (Methodological) (1975): 149-192.

Chan, S. (1988). "Defense burden and economic growth: Unraveling the Taiwanese enigma." The American political science review: 913-920.

Dickey, D. A. and W. A. Fuller (1979). "Distribution of the estimators for autoregressive time series with a unit root." Journal of the American statistical association 74(366a): 427-431.

Dunne, J. P. (1996). "Economic effects of military expenditure in developing countries: a survey." Contributions to Economic Analysis 235: 439-464.

Dunne, J. P., R. P. Smith, et al. (2005). "Models of military expenditure and growth: A critical review." Defense and Peace Economics 16 (6): 449-461.

Dunne, P. (1990). "The political economy of military expenditure: An introduction." Cambridge Journal of Economics 14(4): 395-404.

Engle, R. F., C. W. Granger, et al. (1989). "Merging short-and long-run forecasts: An application of seasonal cointegration to monthly 
electricity sales forecasting." Journal of Econometrics 40(1): 45-62.

Faini, R., P. Annez, et al. (1984). "Defense spending, economic structure, and growth: Evidence among countries and over time." Economic Development and Cultural Change: $487-498$.

Feder, G. (1983). "On exports and economic growth." Journal of development economics 12(1): 59-73.

Foucault, M. (2012). The Defense Budget in France: between Denial and Decline, Paris: IFRI.

Halicioğlu, F. (2004). "Defense spending and economic growth in Turkey: an empirical application of new macroeconomic theory." Review of Middle East Economics and Finance 2(3): 193-201.

Hassan, M. S. and R. Kalim (2012). "The triangular causality among education, health and economic growth: a time series analysis of Pakistan." World Appl. Sci. J 18(2): 196-207.

Huang, C. and A. Mintz (1991). "Defence expenditures and economic growth: the externality effect." Defence and Peace Economics 3(1): 35-40.

Knight, M., N. Loayza, et al. (1996). "The peace dividend: military spending cuts and economic growth." World bank policy research working paper(1577).

Malizard, J. (2010). "Causality between economic growth and military expenditure: The case of France." Defense \& Security Analysis 26(4): 401-413.

Malizard, J. (2013). "Opportunity cost of defense: an evaluation in the case of France." Defence and Peace Economics 24(3): 247-259.

Mankiw, N. G., D. Romer, et al. (1992). "A contribution to the empirics of economic growth." The quarterly journal of economics 107(2): 407-437.

Mylonidis, N. (2008). "Revisiting the nexus between military spending and growth in the European Union." Defence and Peace Economics 19(4): 265-272.

Narayan, P. K. (2005). "The saving and investment nexus for China: evidence from cointegration tests." Applied economics 37(17): 1979-1990.

Pesaran, M. H., Y. Shin, et al. (2001). "Bounds testing approaches to the analysis of level relationships." Journal of applied econometrics 16(3): 289-326.

Pesaran, M. H., \& Pesaran, B. (1997). Working with Microfit 4.0: interactive econometric analysis. Oxford University Press.

Phillips, P. C. and P. Perron (1988). "Testing for a unit root in time series regression." Biometrika 75(2): 335-346.

Pieroni, L. (2009). "Does defence expenditure affect private consumption? Evidence from the United States." Economic Modelling 26(6): 1300-1309.

Ram, R. (1986). "Government size and economic growth: A new framework and some evidencefrom cross-section and time-series data." American Economic Review 76(1): 191-203.

Ram, R. (1995). "Defense expenditure and economic growth." Handbook of defense economics 1: 251-274.

Romer, D. (2000). Keynesian macroeconomics without the LM curve, National bureau of economic research.

Smith, R. and G. Georgiou (1983). "Assessing the effect of military expenditure on OECD economies: A survey." Contemporary Security Policy 4(1): 3-15.

Smith, R. P. (1977). "Military expenditure and capitalism." Cambridge Journal of Economics 1(1): 61-76.

Smith, R. P. (1980). "Military expenditure and investment in OECD countries, 1954-1973." Journal of Comparative Economics 4(1): 1932.

Stevenson, P. (1974). A defense of Baran and Sweezy, JSTOR.

Taylor, J. B. (2000). "Teaching modern macroeconomics at the principles level." American Economic Review: 90-94. 